\title{
INOVASI PELAYANAN KESEHATAN GANCANG ARON DI KABUPATEN BANYUWANGI DALAM PERSPEKTIF MATRIK INOVASI SEKTOR PUBLIK
}

\author{
Anugerah Yuka Asmara \\ Mahasiswa Pasca Sarjana Ilmu Administrasi dan Kebijakan Publik Universitas Indonesia \\ Peneliti Kebijakan Iptek dan Inovasi di Lembaga Ilmu Pengetahuan Indonesia \\ Email: a.yuka.asmara@gmail.com \\ Amy Yayuk Sri Rahayu \\ Guru Besar Ilmu Administrasi dan Kebijakan Publik Universitas Indonesia \\ Email: amy_soeroso@yahoo.com
}

\begin{abstract}
ABSTRAK
Inovasi sektor publik telah menjadi wacana sekaligus praktik yang dilakukan oleh beberapa institusi pemerintah di Indonesia. Salah satu inovasi sektor publik yang cukup memiliki dampak langsung kepada masyarakat ialah inovasi pelayanan publik. Inovasi tersebut telah memberikan iklim positif bagi pengembangan berbagai bentuk inovasi pelayanan publik di organisasi-organisasi publik lainnya. Inovasi pelayanan kesehatan merupakan bentuk inovasi yang cukup sering diperbincangkan baik di kalangan akademisi, praktisi, pemerintah, dan masyarakat sebagai penggunanya. Di Rumah Sakit Umum Daerah (RSUD) Blambangan Kabupaten Banyuwangi, inovasi pelayanan kesehatan Gancang Aron dihadirkan sebagai salah satu solusi untuk mengurangi antrian panjang bagi pasien atau keluarga pasien dalam pengambilan obat di rumah sakit tersebut. Inovasi tersebut telah masuk dalam jajaran Top 40 Inovasi Pelayanan Publik versi Kementerian Pendayagunaan Aparatur Negara dan Reformasi Birokrasi (KemenPAN dan RB). Implementasi inovasi tersebut ternyata bukan hanya perubahan yang terjadi di bagian pelayanan kesehatan saja, melainkan ada perubahan-perubahan yang sebelumnya dilakukan di tataran manajemen organisasi. Studi ini fokus pada praktik inovasi pelayanan kesehatan Gancang Aron di RSUD Blambangan - Kabupaten Banyuwangi. Penelitian ini merupakan jenis penelitian kualitatif- deskriptif yang dilakukan dengan memadukan studi literatur tentang inovasi sektor publik yang diperkuat dengan temuan hasil lapangan. Temuan studi ini ialah bahwa perubahan-perubahan yang dilakukan dalam tataran manajemen organisasi RSUD Blambangan merupakan rangkaian integral dari inovasi pelayanan publik yang dapat dilihat melalui perspektif Matrik Inovasi Sektor Publik.
\end{abstract}

Kata Kunci: Inovasi, Pelayanan Kesehatan, Gancang Aron, Banyuwangi, Matrik

\begin{abstract}
Public sector innovation has been an enticing discourse and practice implemented by governmental agencies in Indonesia. One of popular types of public sector innovation is public service innovation because it directly effects to public as users. Also, it makes positive climate to emerge many innovation forms of public services in Indonesia, particularly on health public service which is widely paid attention by many scholars, practicians, governmental actors, and public as users. In the Blambangan Public Hospital (RSUD-Blambangan) in Banyuwangi Regency, The Gancang Aron innovation is emerged as solution to reduce long queue for patients and their familes in taking medicine in this hospital. This innovation is appreciated as Top 40 of The Best Public Sector Innovation in Indonesia held by Ministry of Administrative and Bureaucratic Reform - Republic of Indonesia. Surely, public service innovation is not singly occurred without absence of any changes at an organization management level. This study focuses on The Gancang Aron innovation at The RSUD-Blambangan in Banyuwangi Regency. This study is a qualitative-descriptive by combining literatures review of public sector innovation and reinforced by field data result. The research finding is that innovation occuring in RSUDBlambangan is integral part of public service innovation that it can be viewed through public sector innovation matrix.
\end{abstract}

Keywords: Innovation, Health Service, Gancang Aron, Banyuwangi, Matrix

\section{PENDAHULUAN}

Inovasi telah menjadi diskusi yang populer baik di kalangan akademisi, pemerintah, praktisi, dan masyarakat di seluruh dunia saat ini. Inovasi yang semula hanya digunakan dalam berbagai aktivitas

di sektor swasta atau bisnis, justru perkembangannya saat ini inovasi juga digunakan di sektor publik. Menurut Valkama et al. (2013), aktivitas-aktivitas inovasi yang dilakukan di sektor publik tidak terlepas dari adanya perubahan global dan tantangan-tantangan yang dihadapi oleh ilmuwan administrasi publik dan organisasi sektor publik dalam merespon perkembangan teknologi dan ekonomi dunia saat ini.

Praktik inovasi sektor publik memang masih relatif baru di beberapa negara. Di Indonesia, studistudi inovasi sektor publik sebenarnya dapat dilihat dari praktik-praktik kebaruan pelayanan publik yang dilakukan oleh Pemerintah Kabupaten Sragen, Provinsi Jawa Tengah di tahun 2001 (Widyahseno, 2015) dan oleh Pemerintah Kabupaten Jembrana, Provinsi Bali di tahun 2004-2005 (Lendong, 2010). Namun demikian, istilah inovasi di awal tahun 2000-an di Indonesia masih belum terdengar 
populer dan menjadi diskursus luas daripada istilah New Public Management (NPM) yang waktu itu menjadi salah satu konsep andalan bagi sebagian besar akademisi di kalangan administrasi publik untuk memperbaiki atau meningkatkan pelayanan publik di Indonesia.

NPM memang menjadi salah satu konsep yang mendasari munculnya berbagai praktik inovasi sektor publik (Hall and Holt, 2008), namun NPM cenderung mengadopsi langsung hampir keseluruhan berbagai praktik di organisasi bisnis untuk diterapkan di organisasi publik, sementara praktik inovasi sektor publik tidak meniru langsung dari praktik di sektor bisnis (Lynn Jr., 2013). Di dalam inovasi sektor publik, perubahan-perubahan yang ada tidak serta hasil dari meniru sepenuhnya aktivitas-aktivitas di sektor bisnis, melainkan perubahan dan perbaikan di sektor publik dapat terinsipirasi dari pengetahuan lokal yang ada dan juga upaya kelanjutan dari aktivitas-aktivitas yang ada di dalam organisasi publik tersebut. Hal inilah yang kemudian menjadi keunikan dari inovasi sektor publik, bahwasanya kebaruan yang ada merupakan hasil dari berbagai faktor internal seperti tuntutan perbaikan organisasi dan eksternal organisasi seperti tuntutan masyarakat yang ingin perubahan pelayanan semakin baik.

Inovasi sektor publik harus memiliki manfaat baik ekonomi dan sosial bagi masyarakat sebagai pengguna layanan tersebut (Fuglsang and Pedersen, 2011). Artinya, inovasi pelayanan publik ialah hasil akhir dari organisasi publik yang manfaatnya dapat dirasakan oleh masyarakat sebagai penggunanya. Salah satu inovasi pelayanan publik yang sering ditemui di Indonesia ialah inovasi pelayanan kesehatan.

Inovasi ini muncul sejak tahun 2000-an yang dimulai oleh Pemerintah Kabupaten Jembrana seperti pemberian pelayanan kesehatan gratis bagi masyarakat miskin (Lendong, 2010) yang kemudian muncul di berbagai daerah seperti inovasi pelayanan kesehatan melalui program Sutera Emas yang bertujuan untuk mendeteksi informasi awal tentang adanya penyakit atau kejadian luar bisa seputar kesehatan yang dikelola oleh Pusat Kesehatan Masyarakat (Puskesmas) Kepanjen Kabupaten Malang (Choiriyah, 2016; Mindarti dan Juniar 2018), inovasi pelayanan kesehatan melalui program home care di Kota Makassar yang bertujuan untuk memberikan pelayanan kesehatan bagi mereka yang tidak mampu ke puskesmas atau rumah sakit karena alasan tertentu (Saenab, 2017; Putra dkk, 2017), dan inovasi pelayanan kesehatan Sakinah untuk menekan angka kematian ibu dan anak yang dilakukan oleh Puskesmas Sempu di Kabupaten Banyuwangi (Anggraini dkk, 2017), dan Inovasi Gancang Aron yang dilakukan oleh Rumah Sakit Umum Daerah (RSUD) Blambangan di Kabupaten Banyuwangi yang bertujuan mengurangi antrian panjang pasien dan keluarga pasien dalam pengambilan obat di RSUD Blambangan (KemenPAN dan RB, 2018).

Studi-studi tersebut menunjukkan bahwa inovasi pelayanan kesehatan sudah tidak asing lagi bagi lembaga penyedia pelayanan kesehatan seperti rumah sakit umum (RSU) Puskesmas. Salah satu rumah sakit yang inovatif dan cukup sering mendapat kunjungan dari berbagai instansi ialah RSUD Blambangan di Kabupaten Banyuwangi. Program inovasi unggulan rumah sakit ini ialah pelayanan kesehatan yang dinamankan Gancang Aron. Istilah ini merupakan kependekan dari "Gugus Antisipasi Cegah Antrian Panjang dengan Antar Obat ke Rumah Pasien". Inovasi ini telah masuk Top 40 Sistem Informsi Inovasi Pelayanan Publik (Sinovik) yang digagas oleh Kementerian Pendayagunaan Aparatur Negara dan Reformasi Birokrasi (KemenPAN dan RB) tahun 2018 (KemenPAN dan RB, 2018).

Keberhasilan RSUD Blambangan dalam menggaungkan inovasi pelayanan kesehatan Gancang Aron telah menarik beberapa instansi pemerintah lain untuk berkunjung dan belajar dari praktik inovasi tersebut terutama di sektor kesehatan. Namun demikian, praktik inovasi pelayanan publik bukan serta merta yang hanya nampak di permukaan, lebih dari itu, ada bentuk inovasi lain yang perlu dilakukan oleh organisasi publik tersebut agar menghasilkan inovasi pelayanan publik. Artinya, tidak setiap organisasi publik mampu meniru dan memodifikasi bentukbentuk inovasi pelayanan publik yang sudah ada di organisasi lain untuk diterapkan di organisasi tersebut tanpa melakukan beberapa bentuk inovasi yang menjadi prasyarat utama dari inovasi pelayanan publik.

Berdasar penjelasan singkat di atas, penulis merasa perlu untuk mempertajam definisi dan kategorisasi inovasi sektor publik, khususnya di bidang pelayanan publik. Studi ini fokus pada salah satu inovasi pelayanan kesehatan dengan nama Gancang Aron yang dilakukan oleh RSUD Blambangan - Banyuwangi. Kategorisasi inovasi sektor publik yang digagas oleh Windrum (2008) menjadi dasar dari pengembangan perspektif matrik inovasi sektor publik. Untuk itu tulisan ini fokus pada 2 (dua) pertanyaan penelitian yaitu:

1) Apa yang dimaksud dengan matrik inovasi sektor publik?

2) Bagaimana praktik inovasi pelayanan kesehatan Gancang Aron yang dilakukan oleh RSUD Blambangan di Kabupaten Banyuwangi dilihat dari perspektif matrik inovasi sektor publik?

Tulisan ini tentu menjawab kedua pertanyaan di atas yaitu, pertama menjelaskan definisi tentang matrik inovasi sektor publik dan kedua mendeskripsikan dan menganalisis praktik inovasi pelayanan kesehatan Gancang Aron yang dilakukan 
oleh RSUD Blambangan - Banyuwangi dilihat dari perspektif marik inovasi sektor publik.

\section{METODE PENELITIAN}

Studi ini merupakan jenis penelitian kualitatifdeskriptif dengan menggunakan data primer berupa hasil wawancara dengan informan di lapangan, pengumpulan dokumen organisasi yang terkait dan didukung dengan penggunaan data literatur. Data literatur menggunakan berbagai hasil riset yang relevan dan dipublikasi di berbagai media publik nasional dan internasional, terutama mengacu pada buku yang berjudul Innovation in Public Sector Services: Entrepreneurship, Creativity and Management tahun 2008 dengan Paul Windrum and Per Koch sebagai editornya.

Tabel 1. Data Informan Penelitian

\begin{tabular}{|c|c|c|c|}
\hline No & $\begin{array}{c}\text { Inisial } \\
\text { Informan }\end{array}$ & Jabatan & Institusi \\
\hline 1 & Ibu A & $\begin{array}{l}\text { Plt Direktur } \\
\text { rumah sakit }\end{array}$ & $\begin{array}{l}\text { RSUD } \\
\text { Blambangan- } \\
\text { Banyuwangi }\end{array}$ \\
\hline 2 & Ibu B & $\begin{array}{l}\text { Kepala unit } \\
\text { instalasi farmasi } \\
\text { dan ketua tim } \\
\text { inovasi }\end{array}$ & $\begin{array}{l}\text { RSUD } \\
\text { Blambangan- } \\
\text { Banyuwangi }\end{array}$ \\
\hline 3 & Bapak A & $\begin{array}{l}\text { Pengemudi ojek } \\
\text { online } \\
\text { pengantar obat }\end{array}$ & $\begin{array}{l}\text { PT Gojek } \\
\text { Indonesia }\end{array}$ \\
\hline 4 & Bapak B & $\begin{array}{l}\text { Kepala sub } \\
\text { bidang } \\
\text { ketatalaksanaan }\end{array}$ & $\begin{array}{l}\text { Bagian } \\
\text { Organisasi - } \\
\text { Sekretariat } \\
\text { Daerah } \\
\text { Pemerintah } \\
\text { Kabupaten } \\
\text { Banyuwangi }\end{array}$ \\
\hline
\end{tabular}

Sumber: Hasil lapangan

Penelitian ini merupakan penelitian literatur yang dikuatkan dengan data lapangan. Karena itu penelitian ini bersifat semi desk-research, karena penelitian yang tidak murni dari studi-studi literatur saja, namun juga menggunakan hasil lapangan. Teknik analisis yang digunakan ialah analisis melalui 4 (empat) tahap yaitu pengumpulan data, reduksi data, penyajian data, dan penarikan kesimpulan (Huberman and Miles, 1983). Studi ini fokus pada bentuk dan praktik inovasi pelayanan kesehatan Gancang Aron yang dilakukan oleh RSUD Blambangan di Kabupaten Banyuwangi termasuk bagaimana munculnya inovasi pelayanan tersebut jika dilihat dari perspektif matrik inovasi sektor publik.

Waktu penelitian ini dibagi 2 (dua) periode yaitu penelitian literatur yang dilakukan sejak 1 September 2018-31 Desember 2018. Sementara, penelitian lapangan dilakukan dalam waktu 2 (dua) minggu secara berturut-turut yaitu dari 19 Maret 2019 - 1 April 2019 di RSUD Blambangan dan Bagian Organisasi Pemerintah Kabupaten
Banyuwangi. Selama 2 (dua) minggu tersebut peneliti juga melakukan observasi terkait praktik pelayanan kesehatan Gancang Aron di RSUD Blambangan dan juga pelayanan kesehatan lain yang merupakan rangkaian dari pelayanan kesehatan di RSUD Blambangan.

\section{HASIL DAN DISKUSI \\ Inovasi}

Inovasi merupakan bahasa serapan dari bahasa Inggris yaitu innovation, istilah ini kemudian merujuk pada sesuatu hal yang baru. Definisi inovasi sangat luas digunakan, terutama oleh organisasi sektor bisnis. Beberapa definisi inovasi yang sering digunakan antara lain yang dikemukakan oleh Rogers (1995) bahwasanya inovasi merupakan ide atau gagasan, praktik, atau objek yang dipersepsikan sebagai sesuatu hal yang baru baik oleh individu atau kelompok organisasi tertentu yang mengadopsi hal-hal baru tersebut.

Menurut Okpara (2007), inovasi merupakan implementasi dari inspirasi kreatif. Studi Pratt (2008) menunjukkan bahwa inovasi bukanlah suatu praktik yang linear, bukan suatu serangkaian tahap kegiatan litbang, paten, hingga komersialisasi. Namun mengacu pada teori Schumpeterian, inovasi ialah hasil dari "creative destruction", dimana inovasi melibatkan banyak aktor dan bagian-bagian pekerjaan tertentu yang hal tersebut terjadi bukan di ruang tertutup, artinya butuh banyak interaksi lintas sektor untuk menghasikan suatu inovasi. Oleh karena itu inovasi dapat terjadi di berbagai unit dan bentuk organisasi manapun.

Studi ini sepakat dengan ketiga definisi di atas bahwa inovasi merupakan hal-hal baru yang berasal dari gagasan kreatif dan kemudian dipersepsikan baru oleh individu atau kelompok organisasi di suatu wilayah tertentu. Inovasi harus lah sesuatu yang implementatif, artinya inovasi merupakan praktik riil dari gagasan-gagasan baru yang dimunculkan oleh individu atau kelompok individu tersebut. Praktik ini dilakukan dengan melibatkan banyak pihak, bukan hanya satu pihak tertentu saja.

\section{Inovasi Sektor Publik}

Inovasi yang semula hanya menjadi ranah sektor bisnis dengan tujuan profit semata, saat ini telah meluas digunakan di sektor publik, atau sektor pemerintah. Inovasi sektor publik memang masih cukup baru dibanding dengan sektor swasta, namun setelah di awal tahun 2000-an studi-studi inovasi sektor publik sudah berkembang dan dipraktikkan di berbagai negara hingga saat ini. Definisi inovasi sektor publik memang tidak terlepas dari pengaruh inovasi sektor bisnis. Namun praktik inovasi sektor publik memiliki khas dari sektor swasta yaitu adanya persetujuan politis yang membolehkan inovasi tersebut terjadi (Windrum, 2008; Lynn Jr., 2013).

Studi ini memberikan definisi inovasi sektor publik sebagai suatu bentuk kebaruan di dalam 
organisasi publik. Kebaruan tersebut dihasilkan dari ide-ide baru yang kemudian diimplementasikan ke suatu praktik/aktivitas riil dan memberikan manfaat sosial dan ekonomi bagi penggunanya. Kebaruan tersebut bukan berarti hal-hal yang benar baru, namun juga hal-hal baru dari tempat lain yang kemudian diadopsi dan diadaptasi/dimodifikasi sesuai dengan kondisi yang ada.

Inovasi sektor publik tentu memiliki karakteristik khusus dengan apa yang ada di sektor swasta. Beberapa studi telah berusaha memberi batasan dan bentuk organisasi sektor publik seperti Windrum (2008) dengan membedakan 6 (enam) bentuk inovasi sektor publik yaitu inovasi pelayanan, inovasi deliveri pelayanan, inovasi administrasi dan organisasi, inovasi konsep, inovasi kebijakan, dan inovasi sistemik. Sementara Gault (2018) cenderung mengacu pada 4 (empat) bentuk inovasi yang mirip dilakukan oleh OECD-Eurostat yaitu inovasi produk, inovasi proses, inovasi organisasi, dan inovasi pemasaran. Tulisan ini fokus pada bentuk inovasi yang disajikan oleh Windrum (2008) karena studi tersebut telah banyak diacu oleh penelitian-penelitian lain terkait inovasi sektor publik seperti studi Bloch and Bugge (2013); Arundel and Huber (2013); Tate et al. (2018); Gault (2018); dan Arundel et al. (2019).

Keenam bentuk inovasi sektor publik menurut Windrum (2008) yang juga ditambah penjelasan dan contoh oleh penulis yaitu:

1. Inovasi pelayanan, suatu bentuk inovasi yang terdapat dalam suatu produk barang dan/atau jasa yang dihasilkan oleh organisasi publik. Dalam hal ini inovasi dapat berupa produk fisik maupun non fisik. Misalnya, inovasi dalam pemberian kartu jaminan kesehatan bagi masyarakat miskin secara gratis.

2. Inovasi deliveri pelayanan, suatu bentuk inovasiyangdilakukandalam

menyampaikan/ mengantarkan suatu bentuk pelayanan publik. Inovasi jenis ini bukanlah produk secara fisik, namun hal yang bisa dirasakan oleh penggunanya. Misalnya, pembagian kartu jaminan kesehatan bagi masyarakat miskin yang dilakukan langsung secara door to door oleh staf pemerintah.

3. Inovasi administrasi dan organisasi, suatu bentuk inovasi yang terjadi di dalam struktur, sistem, prosedur, dan rutinitas di dalam organisasi. Inovasi ini seringkali merupakan perubahan sebagian atau mendasar di dalam sistem internal organisasi. Pada umumnya, inovasi organisasi bisa diartikan sebagai salah satu bentuk dari reformasi birokrasi di Indonesia.

4. Inovasi konsep, suatu bentuk inovasi yang merupakan ide-ide awal atau persepsi untuk mengubah organisasi lebih baik.
Umumnya inovasi ini ada di level visimisi, sasaran, dan strategi organisasi. Misalnya, suatu pimpinan organisasi sedang merumuskan strategi bagaimana bentuk dan tujuan inovasi pelayanan kesehatan dapat sampai di masyarakat miskin secara merata.

5. Inovasi kebijakan, suatu bentuk inovasi yang merupakan kebaruan dari bentukbentuk kebijakan yang akan dan sedang dijalankan. Inovasi ini biasanya dapat dilihat di panduan atau instrumen kebijakan, dan peraturan yang ada. Misalnya, surat keputusan direktur rumah sakit terkait peningkatan jangkauan pelayanan kesehatan yang sebelumnya hanya diberlakukan untuk masyarakat miskin dengan kategori penyakit tertentu, namun diperluas untuk seluruh penyakit tanpa terkecuali, sehingga manfaatnya bisa dirasakan.

6. Inovasi sistemik ialah bentuk inovasi yang merupakan cara-cara dari suatu organisasi dalam menjalin hubungan atau kerjasama dengan organisasi lain baik sesama organisasi sektor publik maupun swasta. Inovasi ini bisa dilihat bagaimana suatu organisasi pemerintah misalnya rumah sakit daerah menjalin kerjasama dengan rumah sakit daerah lain atau organisasi lain non kesehatan yang mendukung dalam peningkatan pelayanan kesehatan publik.

Dari keenam inovasi sektor publik tersebut, ketiga bentuk inovasi yaitu inovasi deliveri pelayanan, inovasi administrasi-organisasi, dan inovasi sistemik merupakan inovasi yang hasilnya bukan produk maupun dokumen, namun bisa dirasakan hasil akhirnya. Namun demikian, ketiga inovasi tersebut dapat dibuat "suatu nama inovasi tertentu dan skema aktivitas yang dilakukan". Sementara inovasi pelayanan (produk), inovasi konsep, dan inovasi kebijakan, ketiganya merupakan bentuk inovasi yang hal itu bisa dilihat sebagai produk/dokumen maupun sebagai hasil akhir yang manfaatnya bisa dirasakan.

Inovasi pelayanan bisa berupa produk kartu jaminan sehat bagi masyarakat miskin, inovasi konsep bisa berupa visi misi baru organisasi yang tercetak dalam dokumen organisasi, inovasi

kebijakan bisa berupa peraturan-peraturan, dokumen perencanaan, dan hal lainnya yang menyangkut produk hukum. Seluruh bentuk inovasi tersebut haruslah memiliki capaian tertentu dan bisa terukur tren perubahannya serta manfaatnya bagi penggunanya.

\section{Inovasi Pelayanan Kesehatan}

Definisi inovasi pelayanan kesehatan tidak terlepas dari 2 (dua) istilah dasar yaitu inovasi dan pelayanan. Definisi inovasi sudah dijelaskan di sub 
bab sebelumnya. Pelayanan diartikan sebagai sekumpulan aktivitas yang dilakukan oleh individu dan/atau sekelompok individu di dalam suatu organisasi untuk memenuhi kebutuhan tertentu baik secara langsung maupun tidak langsung (Mindarti dan Juniar, 2018). Dalam konteks ini pelayanan yang dimaksud ialah pelayanan publik. Menurut Horton (2008), pelayanan publik mencakup 3 (tiga) hal yaitu sekelompok orang yang digaji oleh pemerintah untuk menjalankan fungsi-fungsi administratif, pelayanan yang dilakukan oleh otoritas pemerintah dengan menggunakan dana pemerintah, dan pelayanan yang disediakan oleh agen-agen publik/pemerintah.

Pelayanan kesehatan ialah segala aktivitas atau upaya yang dijalankan oleh agen-agen pemerintah, agen-agen bisnis, dan masyarakat dalam memberikan pelayanan kepada seseorang di bidang kesehatan mulai dari pencegahan penyakit, penyembuhan, dan pengobatan (Mindarti dan Juniar, 2018). Fokus studi ini ialah pada pelayanan publik di bidang kesehatan atau sering disebut sebagai pelayanan kesehatan publik. Pelayanan kesehatan publik diartikan sebagai suatu aktivitas yang struktur untuk pelaksanaan dan cara penyampaian pelayanan di bidang kesehatan, dikelola dan dimiliki oleh publik (pemerintah) (European Observatory and WHO, 2018).

Berdasar definisi-definisi di atas, studi ini mengartikan pelayanan kesehatan sebagai segala bentuk aktivitas yang diselenggarakan oleh agenagen publik/pemerintah yang memiliki otoritas di bidang kesehatan dan didukung oleh fasilitasfasilitas kesehatan tertentu yang bertujuan untuk meningkatkan kualitas kesehatan masyarakat mulai dari pencegahan dan penyembuhan penyakit serta peningkatan kesadaran akan kesehatan.

\section{Matrik Inovasi Sektor Publik}

Windrum (2008) menggagas 2 (dua) bentuk inovasi di bidang pelayanan publik yaitu inovasi produk (barang dan jasa) dan juga cara untuk menyampaikan/deliveri produk (barang dan jasa) tersebut. Kedua inovasi tersebut memang bisa merupakan hal terpisah ataupun bisa menjadi satu rangkaian baik dalam tataran konsep maupun praktiknya. Selain itu, ada bentuk inovasi-inovasi lain yang mungkin dilakukan dan diperlukan dalam mewujudkan inovasi pelayanan publik.

Inovasi-inovasi tersebut bisa berupa inovasi konsep, inovasi kebijakan, inovasi administrasiorganisasi, dan inovasi sistemik. Keempat hal tersebut merupakan inovasi yang dilakukan sebelum inovasi pelayanan publik dilakukan. Artinya, ada tahapan inovasi yang diperlukan sebelum ke tahapan inovasi pelayanan publik yang langsung bersentuhan dengan pelanggan/masyarakat. Namun bukan berarti keempat bentuk inovasi harus ada dan berjalan secara linear, bisa saja hanya satu atau dua bentuk inovasi yang dibutuhkan, dan setiap bentuk inovasi yang ada tidak harus melalui tahapan yang linear.

Adanya bentuk inovasi baik di tataran konsep/ kebijakan/ organisasi/ kerjasama antar organisasi sebagai prasyarat untuk mewujudkan inovasi pelayanan publik yang dilakukan oleh organisasi publik menunjukkan bahwa organisasi sektor publik memang memiliki bentuk aturan dan tata kelola organisasi yang cenderung kaku. Birkland (2015) menyebutkan bahwa organisasi sektor publik sering disebut dengan istilah birokrasi yang dipersepsikan sebagai organisasi yang lamban dalam merespon, memiliki banyak hirarki, dan terikat oleh berbagi prosedur dan aturan. Karena itu, Borins (2001) memberikan alasan mengapa organisasi publik harus berinovasi karena hal tersebut dilakukan untuk menghadapi 5 (lima)

tantangan seperti sistem politik, model kepemimpinan baru, persoalan-persoalan saat ini dan ke depan, persoalan internal organisasi termasuk kebijakannya, dan adanya peluangpeluang baru seperti teknologi atau faktor lainnya.

Organisasi publik yang cenderung kaku karena berbagai aturan, struktur, dan prosedur tentu bukanlah syarat bagi organisasi inovatif. Untuk itulah diperlukan terobosan-terobosan baru di internal organisasi termasuk perubahan konsep dan kebijakan yang mendasari perubahan-perubahan organisasi tersebut. Inovasi pelayanan publik baik produk pelayanan dan deliveri pelayanan merupakan inovasi teknis yang bisa dikatakan inovasi paling akhir yang dilakukan oleh inovasi sektor publik karena berdampak langsung pada masyarakat sebagai penggunanya. Sementara, inovasi konsep yang paling atas dan kemudian inovasi kebijakan (kedua inovasi ini ada di level manajerial/pimpinan organisasi), diikuti inovasi administrasi-organisasi dan inovasi sistemik menjadikan prasyarat dalam mengimplementasikan kedua bentuk inovasi pelayanan publik tersebut.

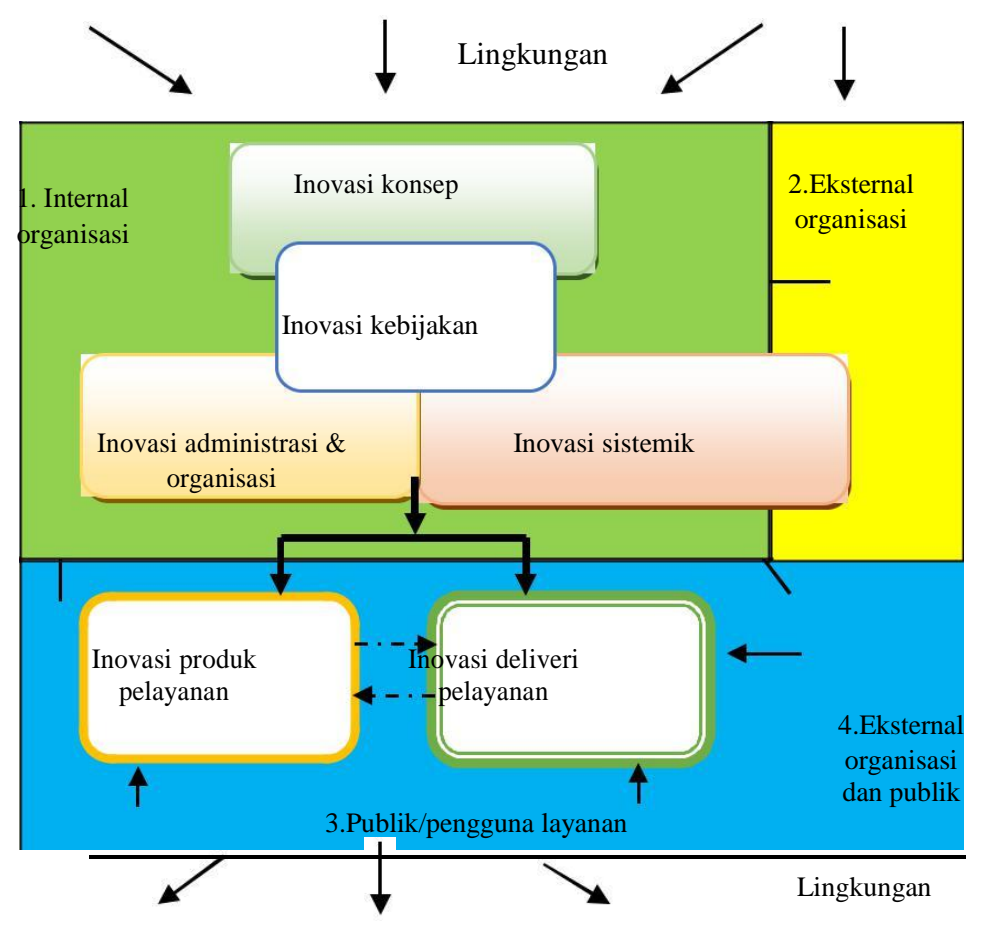


Gambar 1. Matrik Inovasi Sektor Publik

Sumber: Penulis dengan pengembangan konsep dasar dari Windrum (2008)

Gambar di atas membagi 4 (empat) area yang setiap area memiliki keterhubungan antara satu dengan lainnya yang dapat dijelaskan sebagai berikut.

Area I - Internal Organisasi. Pada area ini, hal yang pertama dalam menjalankan inovasi sektor publik ialah melakukan inovasi pada tataran konsep, kebijakan, administrasi-organisasi, dan sistemik. Perubahan-perubahan yang dilakukan bersifat mendasar sebagai prasyarat untuk membuat inovasi-inovasi lain yang sifatnya lebih teknis dan berdampak langsung pada masyarakat/pengguna layanan. Pada area ini, inovasi yang hadir sangatlah kompleks dan bukanlah linear, bisa saja inovasi kebijakan lebih dulu daripada inovasi administrasiorganisasi dan inovasi sistemik, atau sebaliknya yang masing-masing saling memberi masukan terhadap inovasi yang diperlukan. Namun demikian, di sektor publik perubahan kebijakan seringkali mendahului deri perubahan organisasi dikarenakan organisasi publik tidak bisa berjalan tanpa adanya regulasi atau produk kebijakan lain yang mendasarinya. Hal yang pasti ialah adanya inovasi konsep yang melatarbelakangi dari seluruh bentuk inovasi di area I ini.

Area II - Eksternal Organisasi. Pada area ini, inovasi tidak terjadi di suatu organisasi publik, melainkan area ini ialah tempat dimana organisasi-

organisasi eksternal berpengaruh terhadap perubahan pada organisasi publik atau inovasi di area I, atau bisa saja organisasi eksternal mendapat dampak langsung atau tidak langsung dari inovasi yang dilakukan di area I. Seringkali perubahanperubahan tersebut menuju pada kesempatan untuk bermitra atau bekerjasama antara organisasi publik dengan organisasi-organisasi eksternal.

Area III - Publik/Pengguna Layanan. Pada area ini, inovasi pelayanan publik baik produk pelayanan dan/atau deliveri pelayanan muncul. Inovasi bisa terjadi hanya berupa inovasi produk pelayanan atau deliveri pelayanan secara mandiri, atau keduanya bisa terjadi dan saling terkait. Inovasi ini berupa perubahan teknis hasil dari berbagai inovasi yang terjadi di internal organisasi publik (Area I). Tanpa ada inovasi di area I, maka inovasi di area III tidak dapat terimplementasi dengan baik, andaikan muncul pun, maka inovasi tersebut hanya akan muncul sesaat dan kemudian hilang karena ketiadaan perubahan dukungan di level pimpinan dan manajerial. Di area ini, publik atau masyarakat sebagai pengguna layanan ialah mereka yang terkena dampak langsung dari aktivitas organisasi publik ini. Mereka juga dapat memberikan masukan untuk perbaikan inovasi baik yang terjadi di area III maupun di area I.

Area IV - Eksternal Organisasi dan Publik. Pada area ini, tidak ada bentuk inovasi yang tejadi. Area IV merupakan area dimana organisasi eksternal dan publik atau masyarakat sebagai pengguna layanan mendapat dampak langsung dan tidak langsung dari inovasi pelayanan dan inovasi deliveri pelayanan yang dilakukan oleh organisasi sektor publik. Organisasi eksternal dan publik sebagai pengguna layanan juga dapat memberikan masukan terkait bentuk inovasi di area I dan III. Seringkali, organisasi eksternal dan publik merupakan faktor utama yang mendasari berbagai inovasi yang ada di area I dan III.

Keempat area tersebut dipengaruhi oleh suatu sistem yang lebih besar lagi yaitu lingkungan yang terdiri dari berbagai aspek mulai aspek sosial, politik, ekonomi, budaya, teknologi, dan berbagai regulasi-kesepakatan level nasional dan internasional. Lingkungan dapat mempengaruhi tinggi rendahnya tekanan bagi organisasi sektor publik untuk melakukan inovasi secara langsung, dapat mendorong dan mempercepat pengaruh organisasi eksternal dan publik dalam memberi masukan ataupun tekanan bagi organisasi sektor publik untuk berinovasi sesuai permintaan dan kebutuhan mereka. Dampak dari inovasi sektor publik juga memiliki pengaruh terhadap lingkungan yang besar-kecilnya kurang bisa diukur dengan spesifik, dikarenakan aspek lingkungan yang sangat luas dan kompleks serta mudah berubah-ubah dalam waktu yang relatif singkat.

\section{Praktik Inovasi Pelayanan Kesehatan Gancang Aron dilihat dari Perspektif Matrik Inovasi Sektor Publik}

Inovasi sektor publik di bidang pelayanan kesehatan baik itu inovasi dalam bentuk produk

(barang dan/atau jasa) dan cara penyampaian/deliveri pelayanan merupakan inovasi yang langsung bersentuhan dengan pengguna. Di sektor publik, praktik inovasi tersebut bukan serta merta berdasar tujuan dari inovasi yang dihasilkan sebagaimana di sektor swasta, namun ada persetujuan politis dari pimpinan tertinggi atau lembaga perwakilan yang menjadikan praktik inovasi sektor publik lebih kompleks. Untuk itu, suatu organisasi publik penyedia pelayanan kesehatan memerlukan inovasi-inovasi lain sebelum memutuskan untuk melakukan inovasi di pelayanan kesehatan.

Salah satu contoh praktik inovasi sektor publik di bidang pelayanan kesehatan ialah Inovasi Gancang Aron yang dilakukan oleh Rumah Sakit Umum Daerah (RSUD) Blambangan di Kabupaten Banyuwangi. Gancang Aron merupakan singkatan dari "Gugus Antisipasi Cegah Antrian Panjang dengan Antar Obat ke Rumah Pasien" dan merupakan terobosan dalam memecah gelombang 
antrian panjang pasien atau keluarga pasien dalam mendapatkan obat dari poli RSUD Blambangan. Melalui inovasi ini, pasien atau keluarga pasien tidak perlu lagi antri panjang dan berjam-jam dalam mendapatkan obat dari bagian farmasi RSUD Blambangan. Sebelumnya, pasien atau keluarga pasien antri selama berjam-jam di loket pengambilan obat dan tidak mendapat kepastian kapan mendapatkan obatnya, namun dengan inovasi ini, mereka tidak perlu lagi antri obat di rumah sakit, mereka menunggu di rumah setelah pemeriksanaan di poli RSUD Blambangan karena obat akan diantar oleh pengemudi ojek online yang telah bekerjasama dengan RSUD Blambangan.

Inovasi yang diluncurkan sejak tanggal 13 September 2017 dan sampai saat ini telah berhasil mengurangi antrian panjang yang sebelumnya di tahun 2016 seorang pasien atau keluarga pasien mengantri pengambilan obat hingga smpai 240 menit, namun dengan sistem ini antrian pengambilan obat antara 20-40 menit dan maksimal 60 menit. Terkait biaya, akan dilihat apakah pasien merupakan peserta dari program jaminan kesehatan bagi keluarga miskin atau bukan. Jika pasien merupakan peserta dari program tersebut maka tidak dikenakan biaya, namun jika bukan peserta program, maka akan dikenakan biaya sesuai tarif yang berlaku. Inovasi Gancang Aron telah diapresiasi positif oleh pasien dan keluarganya, oleh masyarakat umum, dan oleh pemerintah nasional dengan diberikannya penghargaan di dalam Top 44 Sistem Informasi Inovasi Pelayanan Publik (Sinovik) di tahun 2018.

Gancang Aron merupakan inovasi pelayanan publik dengan kategori cara penyampaian/deliveri pelayanan pengambilan obat di rumah sakit. Artinya RSUD Blambangan telah berupaya untuk memberikan pelayanan ekstra kepada pasien dan keluarganya dengan cara mempermudah cara pengambilan obat di RSUD Blambangan. Untuk menjalankan inovasi ini, manajemen RSUD Blambangan tentu sudah memiliki pemikiran dasar ke arah mana inovasi yang akan dilakukan di RSUD Blambangan untuk memberikan pelayanan kepada masyarakat sekaligus untuk meningkatkan pendapatan bagi RSUD mengingat RSUD ini merupakan bagian dari bentuk Badan Layanan Umum Daerah (BLUD) yang juga memiliki wewenang dalam menarik pendapatan dari pelanggan dan mengelola pendapatan tersebut sesuai dengan kebutuhan dari RSUD yang tetap berdasar pada aturan dari Kementerian Keuangan dan Pemerintah Kabupaten Banyuwangi.

Ide awal mengapa RSUD Blambangan harus berinovasi dikarenakan banyaknya tuntutan dari masyarakat di Kabupaten Banyuwangi sebagai pengguna layanan dan juga semakin bertambahnya rumah sakit swasta di Banyuwangi sehingga membuat manajemen RSUD Blambangan berpikir untuk melakukan terobosan-terobosan baru untuk memenuhi permintaan konsumen serta dapat bersaing dengan beberapa rumah sakit swasta yang ada di Banyuwangi. Faktor pendorong lain ialah naiknya status RSUD Blambangan dari tipe C menjadi rumah sakit tipe B sejak Februai 2017 (Portal Banyuwangi, 2018), sebagai rumah sakit rujukan dari berbagai daerah di sekitarnya, munculnya kebijakan Kementerian Pendayagunaan Aparatur Negara dan Reformasi Birokrasi (KemenPAN dan RB) agar setiap instansi publik di Indonesia memiliki 1 (satu) inovasi (one agency one innovation), dan dorongan Bupati Banyuwangi untuk melakukan inovasi di setiap instansi publik di Kabupaten Banyuwangi (satu unit kerja satu inovasi) guna peningkatan kualitas pelayanan publik. Hal-hal tersebut merupakan aspek lingkungan yang mempengaruhi munculnya inovasi di manajemen internal RSUD Blambangan.

Dukungan politik seringkali menjadi sangat penting sebagaimana studi Cunningham (2013) yang mengungkap bahwa inovasi pelayanan kesehatan publik di Inggris di tahun 1997 dilakukan melalui keputusan politik level tinggi. Pengaruh dari lingkungan tersebut kemudian menjadi dasar dari munculnya berbagai inovasi di internal organisasi mulai dari inovasi konsep, inovasi kebijakan, inovasi administrasi-organisasi, dan inovasi sistemik (Area I).

Inovasi konsep muncul ketika Bupati Banyuwangi menginginkan agar terjadi perubahan mendasar dalam pelayanan kesehatan di rumah sakit. Hal ini kemudian direspon oleh pimpinan dan tim manajemen RSUD Blambangan yang ingin meniru kesuksesan dari PT Kereta Api Indonesia (KAI) yang saat itu dilakukan oleh Direktur Utama Ignasius Jonan untuk membuat PT KAI lebih nyaman dan dipilih oleh penumpang sebagai sarana transportasi unggulan masyarakat di Indonesia. Disinilah kemudian gagasan tersebut dituangkan di dalam strategi manajemen RSUD Blambangan dengan mengubah pola-pola strategi lama bahwasnya rumah sakit milik pemerintah yang berfokus pada pelayanan berbasis anggaran pemerintah, namun saat ini rumah sakit pemerintah harus bisa meningkatkan pemasukan organisasi dan berkompetisi dengan rumah sakit swasta dalam

memberikan pelayanan kesehatan kepada masyarakat. Plt Direktur RSUD Blambangan, Ibu A mengemukakan bahwa jika PT KAI yang merupakan organisasi besar skala nasional saja bisa, mengapa organisasi RSUD Blambangan yang secara lingkup organisasi tidak sebesar PT KAI tidak bisa melakukan.

Inovasi konsep tersebut kemudian diturunkan menjadi inovasi kebijakan yang dirumuskan dan diberlakukan di tataran manajemen internal organisasi RSUD Blambangan. Inovasi kebijakan yang dilakukan oleh pimpinan RSUD Blambangan ialah mendorong agar setiap unit atau instalasi di rumah sakit dapat berkontribusi terhadap penyelesaian berbagai persoalan pelayanan publik di RSUD Blambangan. Perubahan kebijakan ini 
ditunjukkan melalui surat tugas dari Direktur RSUD Blambangan kepada tiap instalasi untuk memperbaiki kualitas pelayanan farmasi. Hanya melalui surat tugas ini, serangkaian program dan aspek legal lain yang mendorong inovasi dapat dilakukan. Kepala Unit Instalasi Farmasi sekaligus ketua tim inovasi, Ibu B bahwasnya inovasi di sektor publik, terlebih lagi rumah sakit adalah keharusan kalau kita ingin eksis, setiap instalasi harus melakukan inovasi. Sebelumnya tidak ada kebijakan seperti ini dikarenakan RSUD Blambangan melalukan proses bisnis pelayanan rumah sakit seperti biasanya.

Inovasi kebijakan ini telah berdampak secara langsung pada perubahan administrasi dan organisasi RSUD Blambangan. Di level manajemen organisasi, telah terjadi banyak perubahan yang mendukung terhadap munculnya inovasi di bidang pelayanan kesehatan. Meskipun tidak semua poses administrasi dan struktur organisasi berubah, namun ada perubahan kecil dan cukup mendasar yang berpengaruh terhadap munculnya berbagai inovasi di RSUD Blambangan. Salah satu inovasi administrasi dan organisasi yang terlihat ialah terbentukya tim kerja di tiap unit atau instalasi yang bekerja untuk menemukan persoalan pelayanan publik dan mencari jalan keluarnya melalui inovasi. Setiap tim di unit/instalasi tersebut yang terdiri dari berbagai tenaga fungsional medis dan tenaga administrasi untuk bersama-sama berkompetisi dalam berinovasi tanpa meninggalkan tugas utama mereka di rumah sakit.

Kebijakan baru ini telah mendorong setiap individu di RSUD Blambangan terus berupaya melakukan inovasi di sela-sela tugasnya sebagai ahli medis atau tenaga pendukung manajemen lainnya. Alhasil berbagai ide baru muncul dari pegawai-pegawai di RSUD Blambangan, yang sebelumnya ide-ide kreatif tersebut tidak pernah muncul di permukaan dan tidak pernah diteruskan hingga ke level pimpinan. Kondisi saat ini berbeda, ide-ide baru tersebut baru kemudian dikumpulkan dan didokumentasi ke dalam repositori data di tiap unit/instalasi di rumah sakit.

Inovasi di dalam organisasi RSUD Blambangan terlihat dengan adanya tambahan tugas bagi tenaga medis dan manajemen, yaitu tugas untuk berinovasi, yang itu juga berpengaruh pada alokasi anggaran dari setiap program/kegiatan yang dijalankan di dalam organisasi tersebut. Sebelumnya kegiatan dilakukan berdasar anggaran pemerintah daerah dan alokasi anggaran dari Kementerian Kesehatan. Namun saat ini, alokasi anggaran didapat juga berupa bantuan dari dana Coroporate Social Responsibility (CSR) yang salah satunya dari PT Aplikasi Kreasi Anak Bangsa (AKAB) yang masih satu manajemen dengan PT Gojek-Indonesia sebesar Rp. 180.000.000 untuk biaya deliveri obat bagi pasien Gancang Aron di tahu 2017-2018. Tentu hal ini akan membuat perubahan terhadap pola administrasi keuangan di RSUD Blambangan.

Inovasi kebijakan juga mendorong adanya inovasi sistemik. Pihak manajemen RSUD

Blambangan menginginkan agar dalam menjalankan kegiatan pelayanan, pihak manajemen RSUD dapat bekerjasama dengan pihak luar yang tidak terbatas pada kerjasama di urusan medis semata yang selama ini dilakukan atau bentuk contracting out berupa pengadaan peralatan kesehatan atau bentuk pelayanan lain, namun juga kerjasama dengan berbagai pihak di urusan non medis yang belum pernah dilakukan sebelumnya.

Dorongan kerjasama ini juga terjadi akibat dorongan dari organisasi eksternal yang dipengaruhi lingkungan, beberapa diantara ialah keinginan Bupati Banyuwangi untuk bekerjasama dengan PT Pos atau ojek online dalam mengantarkan obat ke rumah-rumah pasien, dan kerjasama dengan Bidang Organisasi Pemerintah Kabupaten Banyuwangi selaku koordinator inovasi publik wilayah Banyuwangi. Kerjasama ini kemudian meluas dengan melibatkan Kementerian Kesehatan (Kemenkes) selaku lembaga yang memberi otoritas kesehatan, Badan Pengawas Obat dan Makanan (BPOM) selaku otoritas pengawasan keamanan obat dan makanan, Kementerian PAN dan RB selaku penyelenggara inovasi pelayanan publik, Asosiasi Apoteker Indonesia, Dinas Kesehatan Pemerintah Provinsi Jawa Timur, Fakultas Farmasi Universitas Airlangga (Unair), dan berbagai satuan kerja di Pemerintah Kabupaten Banyuwangi lainnya yang turut berkontribusi terhadap inovasi sistemik ini. Dengan kata lain, inovasi sistemik pasti melibatkan dua area yaitu Area I dan Area II sebagaimana diilustrasikan di Gambar 1 di atas.

Inovasi administrasi-organisasi dan inovasi sistemik ini kemudian juga mempengaruhi inovasi kebijakan dimana pimpinan RSUD Blambangan selanjutnya memberikan keleluasaan bagi tiap tim di tiap unit/instalasi untuk melakukan berbagai kegiatan uji coba dan kerjasama dengan lembaga lain untuk mendukung inovasi di unit kerjanya. Kerjasama dengan Bidang Organisasi Pemkab Banyuwangi pun mulai intens dilakukan untuk mengindentifikasi potensi inovasi yang ada di Banyuwangi. Misalnya, unit farmasi melakukan uji coba pelayanan antar obat gratis secara langsung oleh apoteker rumah sakit ke rumah pasien (door to door) untuk mengurai kepadatan antrian obat di RSUD Blambangan. Praktik ini kemudian sekaligus memberi masukan terhadap bentuk inovasi sistemik yang sedang dijalankan dan berdampak pada bentuk inovasi administrasi-organisasi seperti pengaturan waktu staf dalam pembagian kerja medis dan inovasi pelayanan publik.

Pada akhirnya dengan pertimbangan legalitas, kesehatan, kefarmasian dan atas kesepakatan bersama antar lembaga berwenang serta tidak melanggar aturan kesehatan dan perdagangan obat, 
maka kerjasama antar obat dilakukan antara RSUD Blambangan dengan PT Gojek Indonesia yang mendapat dukungan penuh dari Bupati Banyuwangi. Terdapat 143 pengemudi Gojek di Banyuwangi yang dilatih dan mengikuti program inovasi ini. Salah satu pengemudi Gojek, Bapak A mengatakan bahwa tidak setiap pengemudi Gojek berkesempatan untuk mengantarkan obat dari RSUD Blambangan, hanya mereka yang terlatih saja dan resmi menjalin kerjasama dengan rumah sakit yang dapat mengantarkan obat ke rumah pasien.

Keempat inovasi yang ada di Area I dan adanya pengaruh dari Area II kemudian berimpilikasi pada munculnya inovasi teknis yang langsung berdampak pada masyarakat sebagai pengguna layanan yaitu munculnya inovasi deliveri pelayanan kesehatan untuk mengurangi kepadatan antrian pasien atau keluarga pasien dalam pengambilan obat di RSUD Blambangan yang telah dijelaskan di paragraf-paragraf sebelumnya (Inovasi Gancang Aron). Inovasi ini berada di Area III dimana merupakan hasil akhir dari aktivitas organisasi publik yang dampaknya langsung terasa bagi masyarakat, yaitu pelayanan publik. Bagaimanapun, esensi dari organisasi publik ialah pelayanan publik prima bagi masyarakat sebagai pengguna layanan tersebut. Saat ini, publik di Banyuwangi sebagai pengguna dapat melaporkan atau memberi apresiasi terhadap kinerja organisasi publik melalui berbagai akun media sosial yang terhubung langsung dengan akun milik Bupati Banyuwangi.

Inovasi Gancang Aron ini telah berimplikasi juga pada organisasi eksternal baik langsung maupun tidak langsung yang berada di Area IV. Publik dan organisasi eksternal dapat memberikan masukan kepada inovasi pelayanan publik di Area

III ataupun inovasi konsep, kebijakan, administrasiorganisasi, dan sistemik di Area I. Organisasiorganisasi eksternal seperti PT Gojek Indonesia, BPOM, Kemenkes, Asosiasi Apoteker Indonesia, Kementerian PAN dan RB, Fakultas Farmasi Unair, organisasi pemerintah lain, dan masyarakat sebagai pengguna layanan sedikit banyak telah memberikan pengaruh terhadap inovasi-inovasi yang dilakukan oleh RSUD Blambangan.

Kepala Unit Instalasi Farmasi sekaligus ketua tim inovasi, Ibu B mengatakan bahwa tekanan dan pujian dari organisasi eksternal dan kepuasan konsumen terhadap pelayanan Gancang Aron ini merupakan salah satu motivasi pegawai untuk meningkatkan berbagai bentuk inovasi di RSUD Blambangan. Sehingga bentuk inovasi yang ada harus mulai terdokumentasi dan terhubung dengan satuan kerja lain di Pemerintah Kabupaten Banyuwangi. Hal ini diperkuat oleh Bapak B selaku kepala sub bidang ketatalaksanaan Bagian Organisasi - Pemerintah Kabupaten Banyuwangi bahwa inovasi - inovasi yang dilakukan di satuan kerja Pemerintah Kabupaten Banyuwangi saat ini sudah dikoordinasi di bawah Bagian Organisasi.

Pengaruh dari organisasi eksternal dan publik di Area IV tersebut kemudian ditunjukkan dengan semakin giatnya berbagai aktivitas inovasi yang dilakukan oleh RSUD Blambangan seperti munculnya inovasi pelayanan kesehatan lain seperti Abed Tangi di tahun 2018 yang bertujuan untuk mempercepat pengurusan berkas medis rawat inap, inovasi Jebeng untuk meminimalisir resiko kematian ibu melahirkan yang saat ini sedang dikembangkan, dan saat ini dipersiapkan peluncuran inovasi I-CARE di tahun 2019 sebagai bentuk inovasi pelayanan medis yang bertujuan untuk antisipasi dini kejadian stroke dan resiko kecacatannya.

Ketiga bentuk inovasi tersebut berupa inovasi pelayanan kesehatan yang ada di Area III. Selain itu, muncul inovasi di Area I berupa inovasi kebijakan dengan dikeluarkannya Surat Keputusan (SK) Direktur RSUD Blambangan sebagai dasar pembentukan dan pelaksanaan unit khusus yang bertugas melakukan inovasi dengan nama Unit Inovasi RSUD Blambangan yang kebetulan ketuanya dirangkap oleh Kepala Unit Instalasi Farmasi RSUD Blambangan. Bahkan saat ini ada program "1 minggu 1 inovasi" di RSUD Blambangan. Inovasi ini kemudian akan memberikan dampak luas pada motivasi pegawai RSUD Blambangan untuk menghasilkan berbagai bentuk inovasi lain di organisasi ini.

\section{PENUTUP}

Inovasi pelayanan kesehatan Gancang Aron yang dilakukan oleh RSUD Blambangan bukanlah merupakan inovasi tunggal yang hanya terjadi di bagian pelayanan saja. Lebih dari itu, inovasi ini merupakan rangkaian dari bentuk inovasi-inovasi lain yang sifatnya cenderung integral, namun di beberapa hal prosesnya memang tidak berjalan linear. Artinya, ada beberapa inovasi di tataran manajemen internal organisasi yang harus dilakukan untuk mewujudkan inovasi pelayanan tersebut.

Tiap inovasi yang dilakukan bisa saja pengaruh dari bentuk inovasi tertentu, atau suatu bentuk inovasi bisa mempengaruhi munculnya bentuk inovasi lainnya. Munculnya berbagai bentuk inovasi di organisasi RSUD Blambangan inni juga sarat dipengaruhi oleh organisasi eksternal dan masyarakat sebagai pengguna layanan yang mana aktor-aktor tersebut juga dipengaruhi oleh faktor lingkungan. Demikian pula dampaknya, yang terasa tidak hanya bagi pengguna layanan, tapi juga bagi organisasi itu sendiri. Dengan kata lain, inovasi Gancang Aron bukanlah aktivitas yang terjadi di ruang isolasi, melainkan ada keterlibatan antar aktor di area-area tertentu yang itu berkontribusi terhadap munculnya praktik inovasi tersebut.

Studi ini membatasi lingkungan eksternal atau yang mempengaruhi inovasi di internal organisasi 
RSUD Blambangan seperti arahan dan kebijakan dari Bupati Banyuwangi, kebijakan dari KemenPAN dan RB untuk peningkatan kompetisi inovasi pelayanan publik, regulasi tentang kesehatan dan kefarmasian yang menjadi ranah dari Kementerian Kesehatan dan keterlibatan Ikatan Apoteker Indonesia, Fakultas Farmasi Unair dan kecenderungan masyarakat umum terhadap pelayanan publik.

Organisasi-organisasi eksternal seperti PT Gojek-Indonesia, Bagian Organisasi dan perangkat daerah lain di Pemerintah Kabupaten Banyuwangi, serta masyarakat sebagai pengguna layanan merupakan pihak-pihak yang berada di antara area lingkungan dan area internal RSUD Blambangan. Mereka secara langsung bersentuhan dan menerima pengaruh baik dari lingkungan maupun RSUD Blambangan. Atau, mereka juga berpotensi memberikan pengaruh tidak langsung terhadap lingkungan dan pengaruh langsung terhadap RSUD Blambangan.

\section{KETERBATASAN PENELITIAN}

Penelitian ini hanya dilakukan dengan metode wawancara dan juga observasi kecil di RSUD Blambangan terkait pelayanan kesehatan. Kedepan, studi ini bisa dikuatkan dengan melakukan survei dengan metode kuantitatif terkait adanya keterhubungan dan pengaruh antara bentuk inovasi satu dengan bentuk inovasi lain yang ada di RSUD Blambangan-Banyuwangi. Tujuannya ialah untuk memperkuat temuan konsep dari matrik inovasi sektor publik yang dituangkan dalam studi ini.

\section{UCAPAN TERIMA KASIH}

Penulis mengucapkan banyak terima kasih kepada Saudari Umul selaku staf bagian kepegawaian RSUD Blambangan - Banyuwangi yang telah berkontribusi sebagai penghubung informan di dalam penelitian ini.

\section{DAFTAR PUSTAKA}

Anggraini, Mita Dian; Murdyastuti, Anastasia; dan Wasiati, Inti. 2017. Inovasi Pelayanan SAKINA di Puskesmas Sempu Kecamatan Sempu Kabupaten Banyuwangi (SAKINA Service Innovation at Sempu Public Health Center, Sempu Sub-Regency, Banyuwangi Regency). E-SOSPOL Vol. IV (2): $75-81$.

Arundel, Anthony and Huber, Dorothea. 2013. From too Little to too Much Innovation? Issues in Measuring Innovation in the Public Sector. Structural Change and Economic Dynamics 27: 146-159.

Arundel, Anthony; Bloch, Carter and Ferguso, Barry. 2019. Advancing Innovation in the Public Sector: Aligning Innovation Measurement with Policy Goals. Research Policy 48 (3): 789-798.
Birkland, Thomas A. 2015. An Introduction to the Policy Process: Thories, Concepts, and Models of Public Policy Making, Third Edition. London: Routledge.

Bloch, Carter and Bugge, Markus M. 2013 Public Sector Innovation From Theory to Measurement. Structural Change and Economic Dynamics 27: 133-145.

Borins, Sandford. 2001. Encouraging innovation in the public sector. Journal of Intellectual Capital, Vol. 2 (3): 310 - 319. http://dx.doi.org/10.1108/146919301104 00128.

Choiriyah,Ilmi Usrotin. 2016. Pemberdayaan Masyarakat Melalui Program Sutera Emas (Studi Pada Inovasi Pelayanan Kesehatan Di puskesmas Kepanjen, Kabupaten Malang). JKMP Vol. 4 (1): 57-74.

Cunningham, Paul. 2013. NHS Direct: a UK Health Sector Innovation Study. In Stephen P. Osborne and Louise Brown (Eds.). In Handbook of Innovation in Public Services (pp. 477-495). Cheltenham, UK: Edward Elgar.

European Observatory and WHO. 2018. Organization and Financing of Public Health Services in Europe Country Reports. Copenhagen-Denmark: World Health Organization (WHO) - Regional Office for Europe. Diakses dari http://www.euro.who.int/ data/assets/p df_file/0011/370946/public-healthservices.pdf?ua=1 (8 April 2019).

Fuglsang, Lars and Pedersen, John Storm. 2011. How Common Is Public Sector Innovation and How Similar Is It to Private Sector Innovation? In Innovation in the Public Sector Linking Capacity and Leadership. (pp. 44-60). Palgrave Macmillan, Hampshire, UK.

Gault, Fred. 2018. Defining and Measuring Innovation in All Sectors of the Economy. Research Policy, 47: 617-622.

Hall, Mark and Holt, Robin. 2008. New Public Management and Cultural Change: The Case of UK Public Sector Project Sponsors as Leaders. In Paul Windrum and Per Koch (Eds.), Innovation in Public Sector Services: Entrepreneurship, Creativity and Management (pp. 21-40). Cheltenham, UK: Edward Elgar.

Horton, Sylvia. 2008. History and Persistence of An Idea and An Ideal. In James L. Perry and Annie Hondeghem (Eds), Motivation in Public Management: The Call of Public Service. (pp. 17-32). Oxford-UK: Oxford University Press. 
Huberman, A. Michael and Miles, Matthew B. 1983. Drawing Valid Meaning from Qualitative Data: Some Techniques of Data Reduction and Display. Quality and Quantity, 17:281-339 281.

KemenPAN dan RB. 2018 (22 Oktober). Kementerian PANRB Tetapkan Top 40 Inovasi Pelayanan Publik 2018. Diakses dari

https://www.menpan.go.id/site/beritaterkini/kementerian-panrb-tetapkan-top40-inovasi-pelayanan-publik-2018 18 April 2019).

Lendong, Romanus Ndau. 2010. Inovasi Birokrasi Dan Optimalisasi Pelayanan Publik: Belajar Dari Jembrana, Bali. Humaniora 1 (2): 276-283.

Lynn, Jr., L. E. (2013). Innovation and Reform in Public Administration: One Subject or Two? In

Stephen P. Osborne and Louise Brown (Eds.),

Handbook of Innovation in Public Services (pp. 29-43). Cheltenham, UK: Edward Elgar.

Mindarti, Lely Indah dan Juniar, Arya Pratista Azaria. 2018. Inovasi Layanan Kesehatan Berbasis E-Government (Studi Pada Puskesmas Kecamatan Kepanjen Kabupaten Malang). Journal of Public Sector Innovation Vol 3( 1): 19-27.

Okpara, Friday O. 2007. The Value of Creativity and Innovation in Entrepreneurship. Journal of Asia and Entrepreneurship And Sustainbility, Vol 3 (2): 1-14.

Portal Banyuwangi. 2018 (3 Februari). Kunjungan dari Dinas Kesehatan Provinsi Jawa Timur ke RSUD Blambangan Banyuwangi. Diakses dari http://portal.banyuwangikab.go.id/news/ detail/6425/kunjungan-dari-dinaskesehatan-provinsi-jawa-timur-ke-rsudblambangan-banyuwangi.html.

Pratt, Andy C. 2008. Innovation and creativity. In: Hall, Tim, Hubbard, Phil and Short, John Rennie, (eds.) The Sage Companion to the City. SAGE Publications, London, UK, pp. 138-153.

Putra, Arjuna; Usman, Jaelan; Abdi. 2017. Inovasi Pelayanan Publik Bidang Kesehatan Berbasis Home Care Di Kota Makassar. Kolaborasi - Jurnal Administrasi Publik 3 (3): 294-309. http://journal.unismuh.ac.id/index.php/k olaborasi.

Rogers, E. M. (1995). Diffusion of Innovations (Fourth Edition). New York-USA: The Free Press.

Saenab. 2017. Inovasi Pelayanan Publik Dalam Pelayanan Kesehatan Melalui Program Home Care (Dottorotta) di kota Makassar (The Innovation Of The Public
Service In Health Service Through The Home Care (Dottorotta) Program In Makassar City). Tesis. Administrasi pembangunan - Fakultas ilmu sosial dan ilmu politik - Universitas Hasanuddin. Makassar.

Tate, Mary; Bongiovanni, Ivano; Kowalkiewicz, Marek; Townson, Peter. 2018. Managing the "Fuzzy Front End" of Open Digital Service Innovation in The Public Sector: A Methodology. International Journal of Information Management 39:186-198.

Valkama, P., Stephen, J. B., \& Ari-Veikko, A. (2013). Contexts and Challenges of Organizational Innovation in Public Services. In Pekka, Valkama; Stephen, J. Bailey and Ari-Veikko, Anttiroiko (Eds.), Organizational Innovation in Public Services Forms and Governance (pp. 3-12). Hampshire, UK: Palgrave Macmillan.

Widiyahseno, Bambang. 2015. Inovasi Bupati di Ruang Demokrasi: Upaya Membangun Kesadaran Inovasi Birokrasi. Jurnal Ilmu Sosial dan Ilmu Politik Volume 18 (3):177-195.

Windrum,P. 2008. Innovation and Entrepreneurship in Public Services. In Paul Windrum and Per Koch (Eds.), Innovation in Public Sector Services:

Entrepreneurship, Creativity and Management (pp. 3-20). Cheltenham, UK: Edward Elgar. 